\title{
Blubber thickness in right whales Eubalaena glacialis and Eubalaena australis related with reproduction, life history status and prey abundance
}

\author{
Carolyn A. Miller ${ }^{1, *}$, Desray Reeb ${ }^{2}$, Peter B. Best ${ }^{2}$, Amy R. Knowlton ${ }^{3}$, \\ Moira W. Brown ${ }^{3}$, Michael J. Moore ${ }^{1}$ \\ ${ }^{1}$ Department of Biology, Woods Hole Oceanographic Institution, Woods Hole, Massachusetts 02543, USA \\ ${ }^{2}$ Mammal Research Institute, University of Pretoria, c/o Iziko South African Museum, PO Box 61, Cape Town, South Africa \\ ${ }^{3}$ New England Aquarium, Central Wharf, Boston, Massachusetts 02110, USA
}

\begin{abstract}
The high variability in reproductive performance of North Atlantic right whales Eubalaena glacialis compared to southern right whales Eubalaena australis may reflect differences in lipid reserves. Amplitude-mode ultrasound was used to measure the thickness of right whale integument (epidermis and blubber, herein referred to as blubber thickness) in E. glacialis in the Bay of Fundy, Canada for 5 summer seasons and in E. australis off the South African coast for 2 austral winter seasons. E. glacialis had significantly thinner blubber layers (mean $\pm 1 \mathrm{SD}=12.23 \pm 2.16 \mathrm{~cm}, \mathrm{n}=172$ ) than $E$. australis $(16.13 \pm 3.88 \mathrm{~cm}, \mathrm{n}=117)$, suggesting differing levels of nutrition between the 2 species. Blubber was thickest in females measured 3 to 6 mo prior to the start of pregnancy (E. glacialis), thinner during lactation (E. glacialis, E. australis) and then thicker with time after weaning (E. glacialis). These results suggest that lipids in blubber are used as energetic support for reproduction in female right whales. Blubber thickness increased in calves during suckling (E. glacialis, E. australis) but subsequently decreased after weaning (E. glacialis). Juvenile and adult male E. glacialis blubber thicknesses were compared between years of differing prey Calanus finmarchicus abundances (data from Pershing et al. 2005; ICES J Mar Sci 62:1511-1523); during a year of low prey abundance whales had significantly thinner blubber than during years of greater prey abundance. Taken together, these results suggest that blubber thickness is indicative of right whale energy balance and that the marked fluctuations in North Atlantic right whale reproduction have a nutritional component.
\end{abstract}

KEY WORDS: Right whale - Eubalaena - Blubber thickness · Body condition · Reproduction · Physiology $\cdot$ Energy reserves

Resale or republication not permitted without written consent of the publisher

\section{INTRODUCTION}

The North Atlantic right whale Eubalaena glacialis is listed as Endangered by the International Union for Conservation of Nature (IUCN) (IUCN 2008). The population is small, estimated at a minimum number of 325 in 2007, with an annual growth rate of $1.8 \%$ between 1990 and 2005 (NOAA 2009). Southern right whales Eubalaena australis, in contrast, are listed as Least Concern (IUCN 2008) and are growing at substantially greater rates: 6.8\% during 1971-1998 for the South
African population (Best et al. 2001) and 6.9\% during 1971-1990 for the Argentinian population (Cooke et al. 2001). Survival rates for E. glacialis were lower in the 1990s than in the 1980s (International Whaling Commission 2001), and the continuing mortalities from vessel strikes and fishing gear entanglements (Knowlton \& Kraus 2001, Kraus et al. 2005) are a source of concern (International Whaling Commission 2006). Furthermore, a low reproductive rate and high variability in reproduction also contribute to the endangered status of the species (Kraus et al. 2001, 2005, 2007). Since 1980, 
observed annual calf production fluctuated greatly in E. glacialis (e.g. 1 calf was born in 2000 versus 31 calves in 2001; Kraus et al. 2007), but showed a steady increase in E. australis off the coast of South Africa (Best et al. 2001). Mean calving intervals for mothers of 2 or more calves in the North Atlantic increased from 3.67 yr (1987 to 1992; Knowlton et al. 1994) to over 5 yr (1996 to 2003) and decreased to 3.2 and $3.5 \mathrm{yr}$ in 2004 and 2005, respectively (CIs not stated) (Kraus et al. 2007). In contrast, mean calving intervals for E. australis of the South African population remained steady at 3.12 yr (95\% CI: 3.07, 3.17) from 1979 to 1995 (Best et al. 2001). This striking difference in reproductive performance between the 2 right whale species suggests that an investigation into biological and environmental factors contributing to reproductive success is warranted to achieve a better understanding of the critical status of North Atlantic right whales.

Body fat condition is known to affect fertility in a wide variety of mammalian species (see Young 1976, Frisch 1984, Thomas 1990 for reviews). For example, a minimum level of body fat reserves is necessary for ovulation in humans Homo sapiens (Frisch 1984). Likewise, in domestic ewes Ovis aries a certain body weight and condition score are necessary for optimum ovulation and ovum quality (see McEvoy \& Robinson 2003 for review) and body fat condition is strongly correlated with ovulation (Doney et al. 1982). The primary link between body fat condition and fertility appears to be regulated by leptin, a hormone produced by adipose tissue that acts at the level of the hypothalamus and pituitary to stimulate the release of gonadotropinreleasing hormone $(\mathrm{GnRH}$, which regulates the synthesis and release of the gonadotropins) and luteinizing hormone $(\mathrm{LH}$, which regulates many aspects of gonadal function, including ovulation), respectively (see Zieba et al. 2005 for review).

Relationships between body fat condition and fertility have also been observed in a species of large whale. In fin whales Balaenoptera physalus, strong correlations between body fat condition, food resources and potential fecundity (determined by the proportion of mature non-lactating females with a corpus luteum, which is a measure of ovulation rate) were observed between 1977 and 1984 (Lockyer 1987). This result led us to examine body fat condition of right whales as a potential contributor to the reduced and variable reproductive output of the North Atlantic population.

Blubber is a part of cetacean integument that underlies and interdigitates with the epidermis. It is a highly specialized organ composed of adipose tissue supported by a matrix of fibrous connective tissue, peripheral nerves and vasculature (Simpson \& Gardiner 1972, Ling 1974, Haldiman \& Tarpley 1993, Reeb et al. 2007). Cetacean blubber serves a number of functions, in- cluding maintaining the hydrodynamic shape of the body (e.g. Koopman 1998, Hamilton et al. 2004), insulating the body core (e.g. Doidge 1990, Dunkin et al. 2005), adjusting buoyancy (e.g. Kipps et al. 2002, Dunkin et al. 2010), and storing energy reserves (e.g. Lockyer 1987, Castellini 2000, Koopman et al. 2002). Blubber can account for 15 to $43 \%$ of total body mass in large whales (Lockyer 1991) and accounts for 35 to $45 \%$ of total body mass in congeneric right whales in the North Pacific Eubalaena japonica (Omura et al. 1969). In fin whales, $96 \%$ of the total adipose tissue of the body was located in the blubber (Pond \& Mattacks 1988). The adipose tissue in blubber had a similar capacity for glucose utilization (an estimation of relative metabolic activity) as internal adipose depots (Pond \& Mattacks 1988), suggesting that blubber is an important indicator of large whale energy reserves. Examining patterns in lipid composition (i.e. total lipids, fatty acid composition and protein content) of the blubber also can lead to inferences about certain functions of the blubber, such as metabolic activity and energy storage (e.g. Ackman et al. 1975, Lockyer et al. 1984, Aguilar \& Borrell 1990, Koopman 2007). The lipid content and composition of balaenopterid blubber varied in the following contexts: across the body, with depth from the epidermis, with season and annually paralleling variation in food availability and with reproductive status in females (Lockyer 1986, 1987, Aguilar \& Borrell 1990). These variations suggests that changes to the physiological state of the whale increase mobilization and deposition of lipids from and to the adipose tissue of the blubber. Furthermore, seasonal trends in fattening and thinning in balaenopterid whales are observable in measurements of blubber thickness (see Lockyer 1981 for review).

Information about right whale blubber thickness and body fat condition is comparatively limited. Post mortem measurements combined from a 6 yr collection period suggested that Eubalaena australis blubber thickness does not increase during the summer feeding season (Tormosov et al. 1998). According to photogrammetric measurements of body width in $E$. glacialis and E. australis, dorsal body shape was significantly thinner in lactating females than non-lactating, non-pregnant females (C. A. Miller unpubl. data). Subjective assessments of dorsal body contours in $E$. glacialis indicated that the external appearance of pregnant females was better than that of lactating and resting females (Pettis et al. 2004). However, just how these assessments relate to blubber thickness (Miller Angell 2006) or more generally, to total adiposity, remains undetermined.

Measurements of blubber thickness are commonly used to assess marine mammal body fat condition. Such measurements of blubber thickness are typically 
collected during necropsy with a ruler (e.g. Lockyer et al. 1985, Koopman 1998, Tormosov et al. 1998) or during live-captures with ultrasound (Curran \& Asher 1974, Gales \& Burton 1987). A technique to measure blubber thickness in free-ranging right whales using amplitude-mode ultrasound was developed by Moore et al. (2001). Using this method, acoustic blubber thickness measurements were collected from free-ranging Eubalaena glacialis in the North Atlantic and E. australis off the coast of South Africa to investigate the relationships between blubber thickness and reproduction. Blubber thickness measurements collected from E. glacialis were also compared with life history parameters from the North Atlantic Right Whale Consortium Photo-Identification Database (Right Whale Consortium 2004) and prey abundance in the Gulf of Maine (GoM) (data from Pershing et al. 2005).

\section{MATERIALS AND METHODS}

\section{Data collection}

Right whale blubber thickness was measured using amplitude-mode ultrasound (Panametrics Epoch III and 9100, Olympus NDT). A 0.5 MHz Panametrics A301S transducer mounted on the end of a cantilevered $12 \mathrm{~m}$ carbon-fiber pole (Composite Engineering) was deployed to make brief and perpendicular contact with the dorsal aspect of surfacing right whales from small (6 and $7.6 \mathrm{~m}$ ) boats (Moore et al. 2001). The transducer was cleaned with alcohol between animals, and a medical grade gel was used for acoustic coupling. Data were recorded in real time on a laptop computer using custom software (Upper Cape Systems).

Acoustic blubber thickness measurements were collected from Eubalaena glacialis in Cape Cod Bay Massachusetts, USA, (a winter feeding area) during February and March 1998 and in the Bay of Fundy, Canada, (a summer feeding area) during August and sometimes early September 1998 to 2002. E. australis were measured in St. Sebastian Bay, De Hoop Marine Reserve and Walker Bay (Gansbaai) off the southern coast of South Africa (a winter calving area) during August and September 1999 and October and November 2000. Parallel data from southern right whales in summer feeding areas were not pursued due to logistical constraints of working in remote, open oceans.

A zero-phase forward and reverse digital filter was applied to each ultrasound record to smooth the acoustic signal in a custom graphical user interface (GUI) (Miller Angell 2006) created in Matlab Version 6.1.0.450, Release 12.1 (MathWorks). The strongest, most consistent acoustic reflections with the greatest transmission times, which Moore et al. (2001) demon- strated are characteristic of the deepest subdermal connective tissue sheath (SDS; Pabst 1996) at the blubber-muscle interface (see 'Discussion: Integument morphology and the acoustic assay'), were chosen for measurement. The resultant acoustic transmission times of flight from the chosen reflections were converted to a measurement of distance $(\mathrm{cm})$ using the sound transmission velocity for right whale blubber, $1483 \mathrm{~m} \mathrm{~s}^{-1}$ (Miller Angell 2006). The half-range mode (HRM) (Bickel 2002) of these extracted data was calculated and used as the measurement of blubber thickness for each contact with a whale. The measurements of 'blubber' thickness presented here are measurements of the entire integument because they include all tissue from the surface of the epidermis to the SDS at the blubber-muscle interface.

Blubber thickness varies across the body in cetaceans, and the pattern of variability appears to be species specific (Lockyer et al. 1985, Doidge 1990, Koopman 1998). Although the pattern of variability for right whale blubber has not been defined, blubber thickness data collected at necropsy suggested that the dorsal blubber exhibits low variability in the area approximately between 30 and $50 \%$ of the body length from the snout (Fig. 1). Blubber thickness measurements from free-swimming right whales inadvertently measured more than once in the same field season also indicated low variability in the same area (C. A. Miller unpubl. data). Therefore, to minimize the effect of variability from measurement location along the body, the following analyses were restricted to dorsal measurements collected between 30 and $50 \%$ of the body

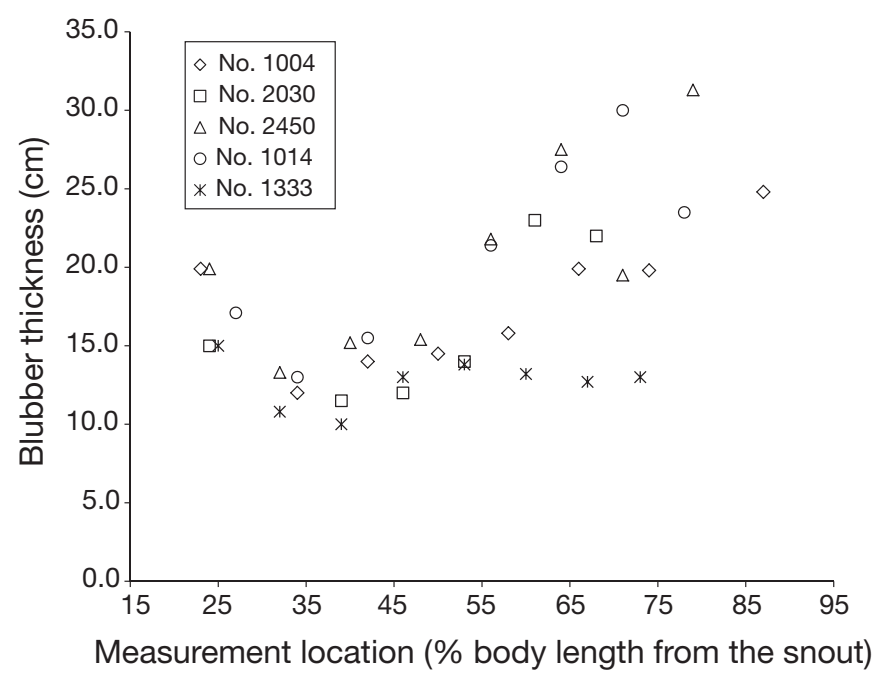

Fig. 1. Eubalaena glacialis. Measurements of blubber thickness (epidermis and blubber) collected with a ruler during necropsies from positions along the dorsal midline of 4 adult females and 1 adult male right whale. Specimen nos. are individual whale identification numbers in the North Atlantic Right Whale Catalog (Hamilton et al. 2007) 
length from the snout. Measurement locations were determined from the oblique-aerial, digital video footage of each measurement event. With the exception of calves, if an individual whale was measured more than once during a field season within the restricted area on the body, the mean of the measurements from that season was used as the blubber thickness for that individual whale. The 30 to $50 \%$ region was also the most consistently accessible.

Total length was measured using aerial photogrammetry (W. L. Perryman unpubl. data). Perpendicular aerial photographs of Eubalaena glacialis were collected with a $126 \mathrm{~mm}$ format KA76 military reconnaissance camera (image size $114 \times 114 \mathrm{~mm}$ ) from a Twin Otter airplane during August 2000, 2001 and 2002 in the Bay of Fundy, Canada. The camera was mounted vertically over a camera port in the deck of the aircraft and was operated by an observer stationed at the right forward bubble window. As each photograph was taken, a computer-based data acquisition system recorded time, GPS position and altitude from a Honeywell AA300 series radar altimeter. Altitudes for photo passes ranged between 150 and $250 \mathrm{~m}$. Camera cycle rate was adjusted to provide 60 to $80 \%$ overlap between successive images. The photographs used in the study were taken with Kodak Aerochrome HS film (SO-359).

\section{Ultrasound comparability, accuracy and precision}

The Epoch III ultrasound was used to measure blubber thickness only in 1998 (Moore et al. 2001) because, with such brief contact durations (often $<1 \mathrm{~s}$ ) with the whales, its $2 \mathrm{~Hz}$ sampling rate limited the quantity and quality of data collected. The Panametrics 9100 ultrasound, deployed during the 1999 to 2002 field seasons, provided a faster sampling rate of $20 \mathrm{~Hz}$, which supplied ample data for measuring blubber thickness. Laboratory testing of ultrasound comparability on Eubalaena glacialis blubber samples collected at necropsy indicated that the 2 ultrasound units provide comparable data (paired $t$-test: $t_{4}=1.845, \mathrm{p}>0.05$ ) (Miller Angell 2006). Therefore, the data sets collected by both systems were combined and used in the following analyses.

Laboratory testing of ultrasound accuracy on Eubalaena glacialis blubber samples collected at necropsy indicated that the mean difference between blubber thicknesses measured with a ruler and those measured by ultrasound $(3.4 \pm 2.8 \mathrm{~mm}, \mathrm{n}=5)$ was not significantly different from zero (paired $t$-test: $t_{4}=$ 2.679, p > 0.05) (Miller Angell 2006). As such, the ultrasound systems can be regarded as being accurate to $3 \mathrm{~mm}$.
To assess measurement precision, coefficients of variation (CV) were calculated from the extracted data from 30 measurement events chosen at random (mean $=1.7 \%$, range $=0.2$ to $4.2 \%$ ). The low CVs indicated low variability in the blubber thickness data from within a measurement event on free-ranging whales. This variability from within a measurement event was likely a result of 3 factors: (1) quality of the contact with the whale, (2) movement of the whale at the time of contact, and (3) choice of acoustic peak during data extraction. To minimize the effects of these sources of variability, the half-range mode (Bickel 2002) was applied to the extracted data and used as the blubber measurement for each contact with a whale. CVs also were calculated from blubber thickness measurements collected from whales measured 3 or more times during one field season (mean $=6.5 \%$, range $=1.1$ to $17.8 \%, \mathrm{n}=16$ ). These CVs were higher, most likely because blubber thickness varies along the body of an individual whale (see 'Data collection'). Although measurement location was limited to an area of low variability along the body, this area is not uniform (Fig. 1). Finally, at-sea blubber thickness measurements are made from fibro-elastic material in an animal that is swimming by flexing and extending its body; thus, some degree of variability is inherent in the live system.

\section{Right whale identification and demographic classification}

Right whales were individually identified by the patterns of callosities on the top and sides of their heads, patterns of skin pigmentation, and any scarring (Best 1990, Hamilton et al. 2007) from $35 \mathrm{~mm}$ photographs taken at the time of measurement. Life history data on individual Eubalaena glacialis were obtained from the North Atlantic Right Whale Consortium PhotoIdentification Database, version dated June 29, 2004 (Right Whale Consortium 2004). Life history data on individual adult female E. australis of the South African population were obtained from a photo-identification database created from aerial photographs collected annually during helicopter surveys between 1979 and 2002 (P. B. Best unpubl. data).

For Eubalaena glacialis, the sex of individual whales was established from photographic observation of the genital area, molecular markers (Brown et al. 1994) or, for females, close and consistent association with a new born calf (Knowlton et al. 1994). Actual age was determined when year of birth was known, while age class (calf, juvenile, or adult) was based on actual age or length of sighting history. Whales were considered calves for all sightings within the first year of life. Since data from Hamilton \& Cooper (2010) suggest that peak 
calving occurs in December or January and the blubber thickness measurements were collected from late July to early September, calves were approximately 8 to 9 mo old when measured. Sexual maturity occurs at approximately 9 yr of age (Kraus et al. 2001); therefore, whales were classified as juveniles if they were between the ages of 1 and $8 \mathrm{yr}$ and as adults if they were $\geq 9 \mathrm{yr}$ old, had a sighting history of at least $9 \mathrm{yr}$ (Hamilton et al. 1998) or, for females, if they were consistently sighted in close association with a calf (Knowlton et al. 1994). Males were assumed to reach sexual maturity at the same age as females.

Adult female Eubalaena glacialis were classified according to their reproductive status (lactating, prepregnant, pregnant, resting, nulliparous) at the time of measurement. Lactating females were those that had been sighted consistently with a calf since the winter calving season. At the time of measurement, females in this category had been lactating for approximately 8 mo and because weaning typically occurs approximately 10 to 12 mo after calving (Hamilton et al. 1995, Hamilton \& Cooper 2010) were considered to be in late lactation. Pre-pregnant females were those measured 3 to 6 mo prior to the estimated start of pregnancy. The estimated start of pregnancy was back-calculated by subtracting gestation duration (estimated as 357 to $396 \mathrm{~d}$; Best 1994) from the estimated month of calving (month of the first sighting with a calf during the calving season). Only one female was measured while pregnant; she was sighted in consistent, close association with a calf during the subsequent winter calving season. Resting females were those that had been sighted consistently with a calf at least once in their sighting history and were not classified as prepregnant, pregnant, or lactating. Resting females could not be subdivided by the number of years resting because of limited sample sizes, so the category includes females that were resting between $8 \mathrm{mo}$ and 6 yr. Nulliparous females were those that had never been observed consistently in close association with a calf in their sighting histories. Females were also classified as nulliparous from age 9 until their first pregnancy (back-calculated from the first calving event).

Eubalaena australis of the South African population were measured during the winter calving season, which extends from late June to late October with peak calving in August (Best 1994). Whales were classified as mothers if observed in close, consistent association with a calf. Calves were classified as such based on small size and close, consistent association with a large whale, the presumed mother. Juveniles were classified subjectively in the field as any whale obviously smaller than an adult female, larger than a calf and lacking the dip in the posterior rostrum characteristic of neonate and younger calf right whales. The consequence of subjectively classifying juveniles in the field was that only the smaller, younger juveniles could be consistently determined. Whales were classified as adult females if they had been sighted with a calf in previous years or were known to be a mother in the given measurement season. Mothers and calves were considered to be lactating and suckling, respectively, given that they were measured within the first few months of birth and weaning is thought to occur 10 to 12 mo after birth (Hamilton et al. 1995). Based on the characterization of the E. australis calving season by Best (1994), mothers and calves measured in September 1999 were considered to have been in the early stage of lactation-suckling. The mothers and calves measured in November 2000 may have been lactating and suckling for a few days but more likely 2 to 4 mo, so the measurements made in November were classified as 'mid-lactation-suckling' measurements.

\section{Prey abundance}

To examine blubber thickness in the context of prey abundance, a Calanus finmarchicus abundance index created by Pershing et al. (2005) was chosen. This annual index used raw C. finmarchicus abundance measured by the GoM Continuous Plankton Recorder (CPR) Program from 1961 to 1974 and 1978 to 2003 in the GoM. The GoM encompasses and is juxtaposed to many of the Eubalaena glacialis feeding habitats. Furthermore, interannual variability in the GoM appears to capture variability over much of the Northwest Atlantic shelf (Pershing et al. 2010).

\section{Statistical analyses}

Statistical analyses were conducted using Systat, version 10.0 (SPSS) and Matlab, version 6.1.0.450, release 12.1 (MathWorks). Because a relationship between blubber thickness and total length was found only in juveniles and unknown age whales (see 'Results') and total length measurements were not available for all of the whales in the blubber thickness data set, the raw, uncorrected blubber thickness data were used for all analyses except one. The ratio of blubber thickness to total length was used in a comparison between calves and yearlings.

\section{RESULTS}

Between 1998 and 2002, 172 blubber thickness measurements were collected from Eubalaena glacialis. Mean blubber thickness was $12.23 \mathrm{~cm}(95 \% \mathrm{CI}=$ 


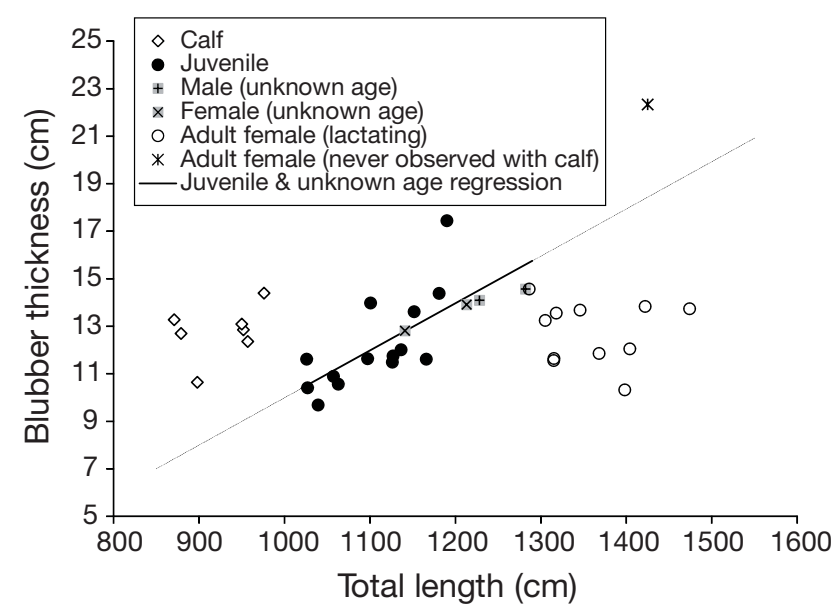

Fig. 2. Eubalaena glacialis. Acoustic measurements of blubber thickness (epidermis and blubber) compared with photogrammetric measurements of total body length (snout to fluke notch) made in the Bay of Fundy, Canada, during August 2000 to 2002. The adult female never observed with a calf had a 26 yr sighting history. The relationship between total length and blubber thickness found in juveniles and unknown age whales (bold line), regression equation: $y=$ $0.01988 x-9.89610, R^{2}=0.56, p=0.0004$ was extrapolated to the full range of whale body lengths for this species (thin line)

$11.90,12.55 ;$ range $=7.93$ to 22.33). During 1999 and 2000, 117 blubber thickness measurements were collected from E. australis. Mean blubber thickness was $16.13 \mathrm{~cm}(95 \% \mathrm{CI}=15.41,16.84$; range $=4.89$ to 25.82$)$.

\section{Blubber thickness and total length of Eubalaena glacialis}

No apparent relationship was found between blubber thickness and length in whales for which total length and blubber thickness measurements were available (Pearson's correlation: $\mathrm{r}=0.21, \mathrm{p}=0.22, \mathrm{n}=$ 36; Fig. 2). However, when these whales were divided according to age class, blubber thicknesses of juvenile and unknown age whales increased with increasing total length $\left(y=0.01988 x-9.89610, \mathrm{R}^{2}=0.56, \mathrm{p}=\right.$ 0.0004, n=18; Fig. 2).

\section{Blubber thickness and age}

\section{Eubalaena glacialis}

Blubber thickness measurements were tested among calves and juveniles of various ages with a 1-way ANOVA and a Tukey pairwise comparisons test. Uncorrected blubber thickness data were used in this ANOVA because total length measurements were lacking for most individuals. The results of the posthoc tests indicated that 8 mo old calves had significantly thicker blubber (mean $\pm 1 \mathrm{SD}=12.58 \pm 1.16 \mathrm{~cm}$, $\mathrm{n}=8)$ than $2 \mathrm{yr}$ olds $(10.01 \pm 1.42 \mathrm{~cm}, \mathrm{n}=12, \mathrm{p}=0.006$; Fig. 3a) and 8 yr olds had significantly thicker blubber than 1, 2, 3 and 4 yr olds ( $p<0.01$, Fig. 3a).

Three individual right whales measured as calves (8 mo old) and again as yearlings (20 mo old) showed a $1.7 \mathrm{~cm}$ decrease in blubber thickness from calf to yearling (Fig. 3b). Also, among the calves and yearlings measured in 2001 and 2002, blubber thickness corrected for total length was significantly greater for calves $(1.38 \pm 0.12 \mathrm{~cm}, \mathrm{n}=7)$ than for yearlings $(1.07 \pm$ $0.12 \mathrm{~cm}, \mathrm{n}=6)\left(2\right.$-sample $t$-test: $t_{11}=4.771, \mathrm{p}=0.0003$; Fig. 3c).
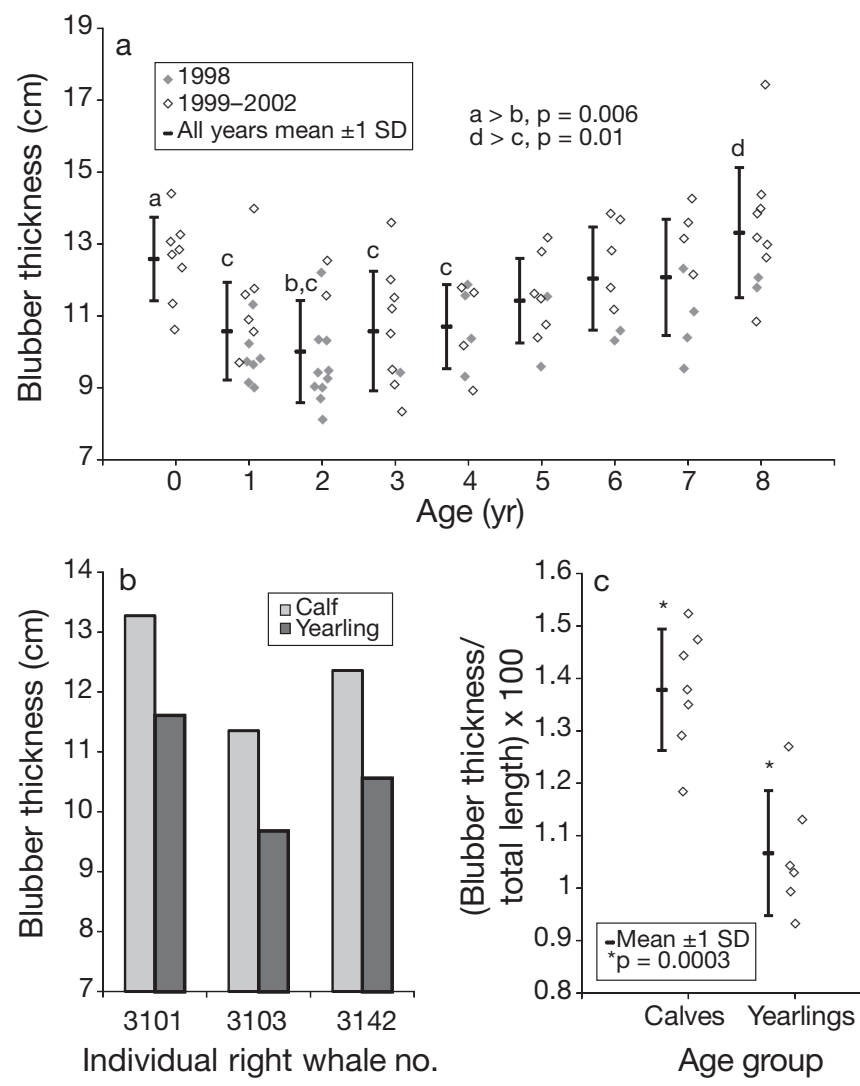

Fig. 3. Eubalaena glacialis. (a) Acoustic blubber thickness measurements from calves and juveniles (randomly jittered with respect to age with mean $\pm 1 \mathrm{SD}$ ) between ages 0 and $8 \mathrm{yr}$ old in the Bay of Fundy, Canada, from 1998 to 2002. Letters indicate significant differences between means. (b) Blubber thickness of 3 individuals sampled as 8 mo old calves and again as 16 mo old yearlings in the Bay of Fundy, Canada, from 2001 to 2002. Specimen nos. refers to the individual whale identification numbers in the North Atlantic Right Whale Catalog (Hamilton et al. 2007). (c) Acoustic blubber thickness measurements as a percentage of total body length for calves and yearlings (randomly jittered with respect to age with mean $\pm 1 \mathrm{SD}$ ) in the Bay of Fundy, Canada, from 2001 to 2002 


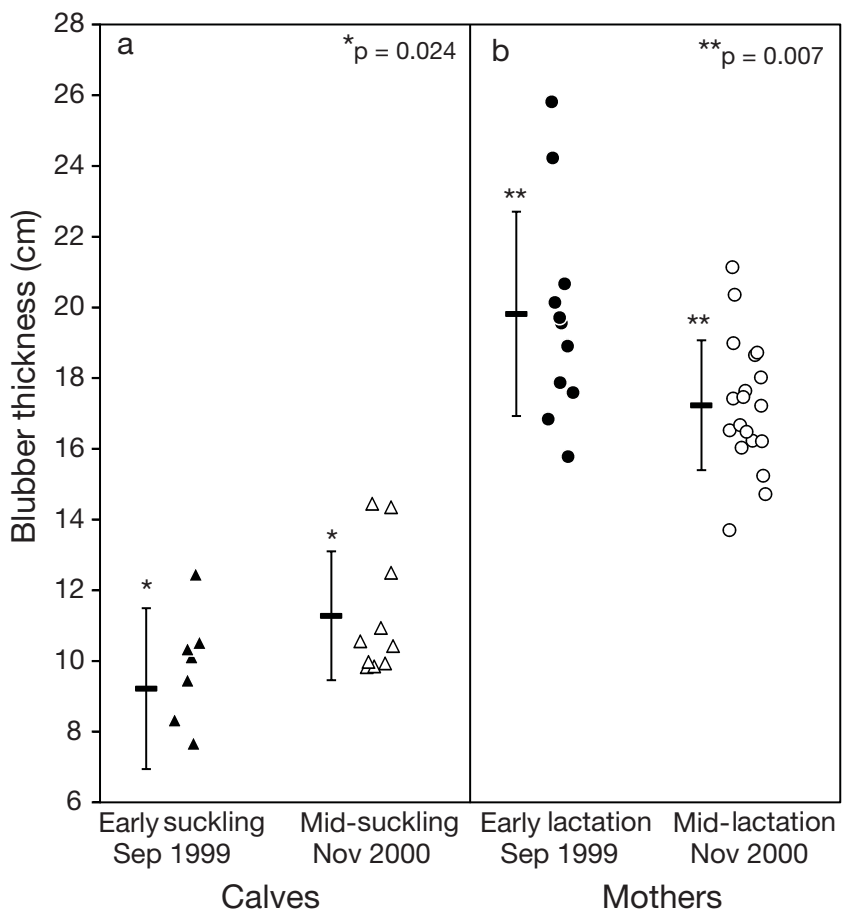

Fig. 4. Eubalaena australis. Blubber thickness measurements (randomly jittered) collected by ultrasound from (a) calves and (b) mothers during early (September 1999) and mid (November 2000) lactation with mean \pm 1 SD in the St. Sebastian Bay, De Hoop Marine Reserve and Walker Bay (Gansbaai), South Africa from 1999 to 2000

\section{Eubalaena australis}

Blubber thickness of calves measured during early suckling in September $1999(9.22 \pm 2.28 \mathrm{~cm}, \mathrm{n}=8)$ was significantly thinner than that of calves measured during mid-suckling in November $2000(11.28 \pm 1.8 \mathrm{~cm}, \mathrm{n}=10)$ (2-sample $t$-test: $t_{16}=-2.133, \mathrm{p}=0.024 ;$ Fig. $4 \mathrm{a}$ ).

\section{Blubber thickness and prey abundance for Eubalaena glacialis}

Calanus finmarchicus abundance in the GoM declined dramatically in 1998 to the third lowest value in the entire Pershing et al. (2005) time series behind those of 1961 and 1970. Abundance recovered in 1999 and 2000 relative to 1998, although the values for these 2 years still remain below the mean of the values of the entire time series (as indicated by the dotted line in Fig. 5). C. finmarchicus abundance increased above the time series average in 2001 to 2003.

Yearlings measured in 1998 had significantly thinner blubber $(9.85 \pm 0.77 \mathrm{~cm}, \mathrm{n}=7)$ than those measured in $2002(11.42 \pm 1.46 \mathrm{~cm}, \mathrm{n}=6)\left(2\right.$-sample $t$-test: $t_{11}=$ $-2.462, \mathrm{p}=0.016$; Fig. 5).

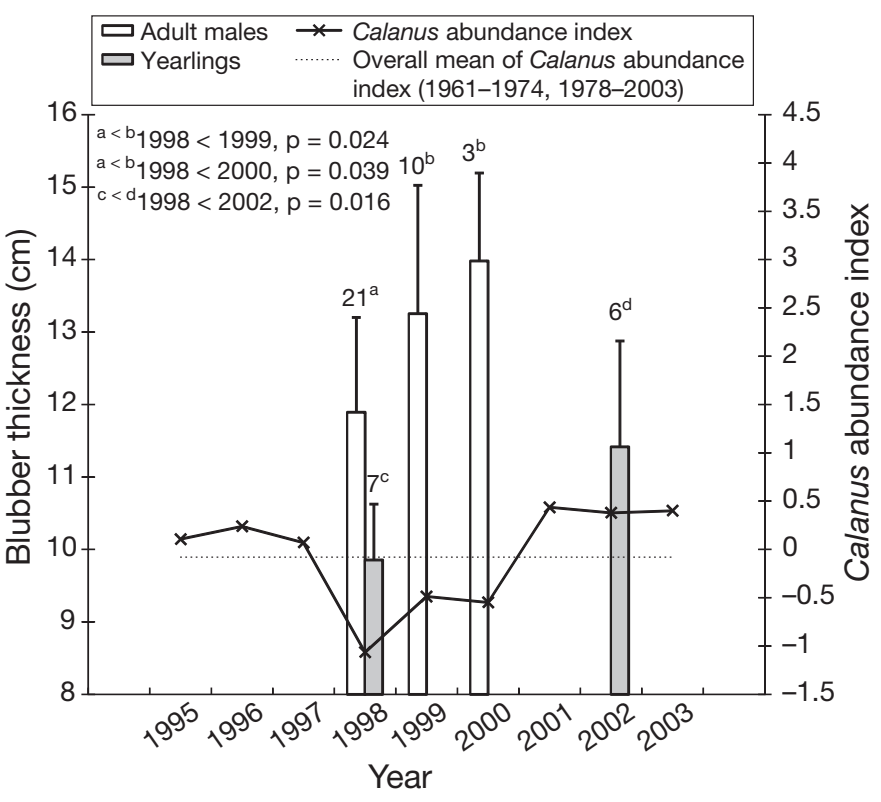

Fig. 5. Eubalaena glacialis and Calanus finmarchicus. Mean blubber thickness (+1 SD) measured with ultrasound from adult male and yearling right whales in the Bay of Fundy, Canada, from 1998 to 2002. Numbers above columns show sample sizes for each year (solid line). Yearly means of the differences between observed log-transformed abundance data measured by Continuous Plankton Recorder in the Gulf of Maine and the expected abundance (climatological seasonal cycle) from Pershing et al. 2005 (dotted line). Mean of the yearly abundance deviations from 1961 to 1974 and 1978 to 2003 plotted for reference to the entire Pershing et al. (2005) time-series. Significant differences are denoted by different letters at $\mathrm{p}<0.05$

Adult males measured in 1998 had significantly thinner blubber $(11.89 \pm 1.31 \mathrm{~cm}, \mathrm{n}=21)$ than those measured in $1999(13.25 \pm 1.77 \mathrm{~cm}, \mathrm{n}=10)$ (Smith-Satterthwaite unpooled $t$-test [Devore 1995]: $t_{14}=2.162, \mathrm{p}=$ $0.024)$ and in $2000(13.98 \pm 1.21 \mathrm{~cm}, \mathrm{n}=3$; SmithSatterthwaite $t$-test: $t_{3}=2.759, \mathrm{p}=0.039 ;$ Fig. 5). The blubber thickness of adult males measured in 1999 did not differ statistically from that of the males measured in 2000, according to a Smith-Satterthwaite $t$-test $\left(t_{5}=\right.$ $0.811, \mathrm{p}=0.455 ;$ Fig. 5).

\section{Blubber thickness and reproduction}

\section{Eubalaena glacialis}

Pre-pregnant females had significantly thicker blubber $(17.23 \pm 0.67 \mathrm{~cm}, \mathrm{n}=4)$ than lactating females $(12.73 \pm 1.31 \mathrm{~cm}, \mathrm{n}=11)$ (Smith-Satterthwaite $t$-test: $t_{11}=8.712, \mathrm{p}<0.0001$; Fig. 6) and had significantly thicker blubber than nulliparous females (13.64 \pm $1.44 \mathrm{~cm}, \mathrm{n}=8$; Smith-Satterthwaite $t$-test: $t_{10}=5.898$, 


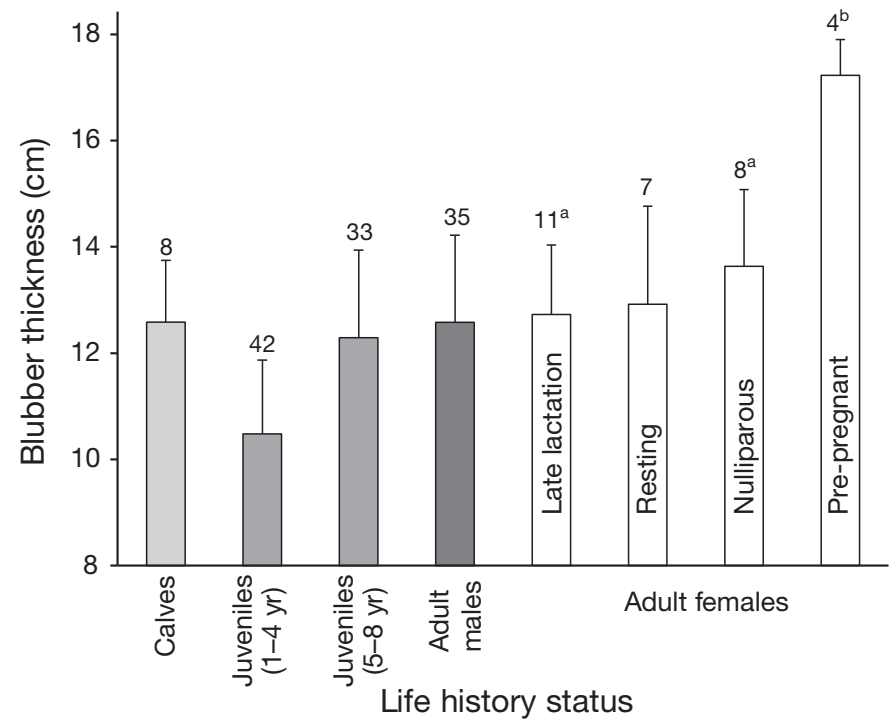

Fig. 6. Eubalaena glacialis. Mean blubber thickness (+1 SD) measured with ultrasound from adult females of different reproductive status, adult males, juveniles and calves in the Bay of Fundy and Cape Cod Bay during 1998 to 2002. Numbers above bars indicate sample sizes. Significant differences between means are marked with different letters $(\mathrm{a}<\mathrm{b}, \mathrm{p}<0.001)$

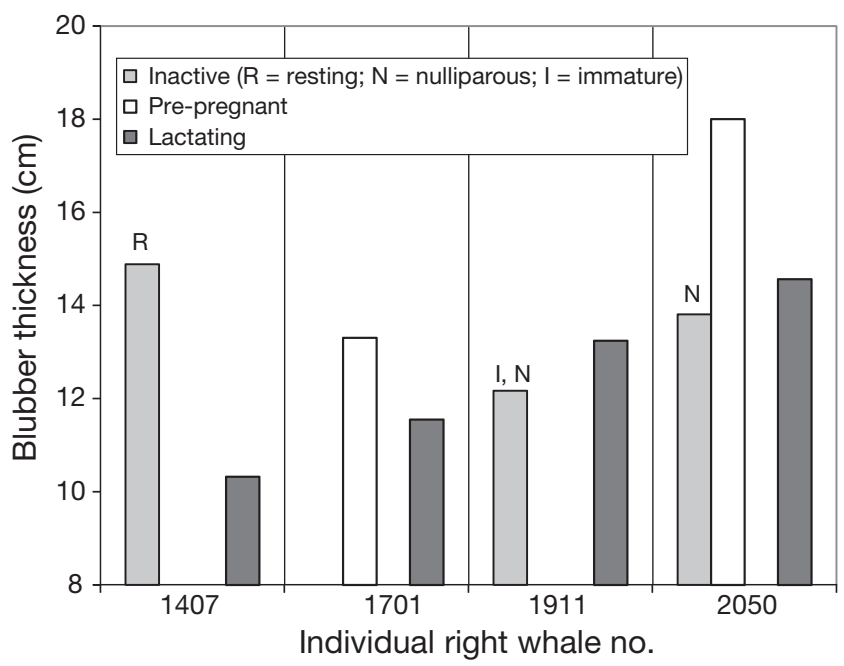

Fig. 7. Eubalaena glacialis. Blubber thickness collected by ultrasound from 4 individual females measured in multiple years at different stages of the reproductive cycle in the Bay of Fundy, Canada, during 1998 to 2002. Specimen nos. are individual whale identification numbers in the North Atlantic Right Whale Catalog (Hamilton et al. 2007)

$\mathrm{p}<0.0001$; Fig. 6). The blubber of nulliparous females did not differ from lactating females (2-sample $t$-test: $t_{17}=1.427, \mathrm{p}=0.17$; Fig. 6 ). Due to a sample size of one, the measurement from the pregnant female was not included in the analysis.

Four individual females were measured in multiple years at different stages of the reproductive cycle

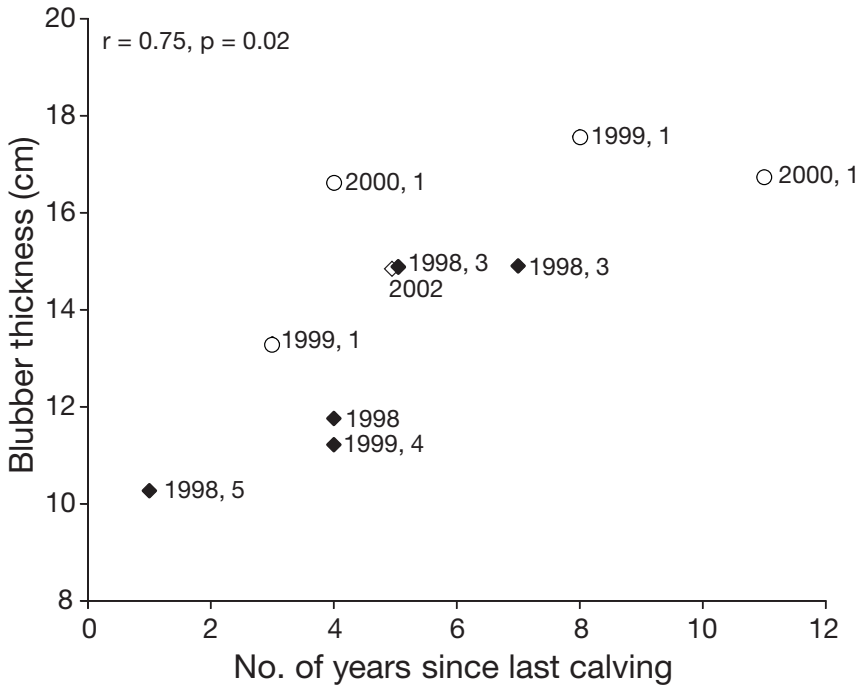

Fig. 8. Eubalaena glacialis. Blubber thickness and no. of years since last calf in reproductively active adult females in the Bay of Fundy, Canada, from 1998 to 2002. Data points are labeled with year measured and number of years to subsequent calving. $(\diamond)$ resting; $(\diamond)$ pregnant; $(O)$ pre-pregnant $(\mathrm{PP})$

(Fig. 7) and are referred to by their identification number from the North Atlantic Right Whale Catalog (Hamilton et al. 2007). The blubber of whale no. 1407, measured in 1998 after resting for $3 \mathrm{yr}$, was $4.6 \mathrm{~cm}$ thicker than the measurement collected in 2001 after 8 mo of lactation, while whale no. 1701's blubber was $1.8 \mathrm{~cm}$ thicker when measured in 1999 within a few months of pregnancy than in 2001 after 8 mo of lactation. When whale no. 1911 was measured in 1998 as an immature, nulliparous female, her blubber was $1.1 \mathrm{~cm}$ thinner than when she was measured in 2001 after 8 mo of lactation. Whale no. 2050 was measured 3 times. Between 1998 and 1999, her blubber thickness increased by $4.2 \mathrm{~cm}$ as she transitioned from nulliparous to pre-pregnant. Her blubber then decreased by $3.4 \mathrm{~cm}$ in 2001 after 8 mo of lactation.

In reproductively active females, a positive relationship was found between blubber thickness and number of years since last calving (Pearson's correlation: $\mathrm{r}=$ 0.75, $\mathrm{p}=0.02$, $\mathrm{n}=9$; Fig. 8).

\section{Eubalaena australis}

Mean blubber thickness from mothers measured in September 1999 during early lactation (19.82 \pm $2.89 \mathrm{~cm}, \mathrm{n}=12$ ) was significantly thicker than the mean of those measured in November 2000 during mid-lactation $(17.24 \pm 1.84 \mathrm{~cm}, \mathrm{n}=19)(2$-sample $t$-test: $t_{17}=2.761, \mathrm{p}=0.007$; Fig. 4b). 


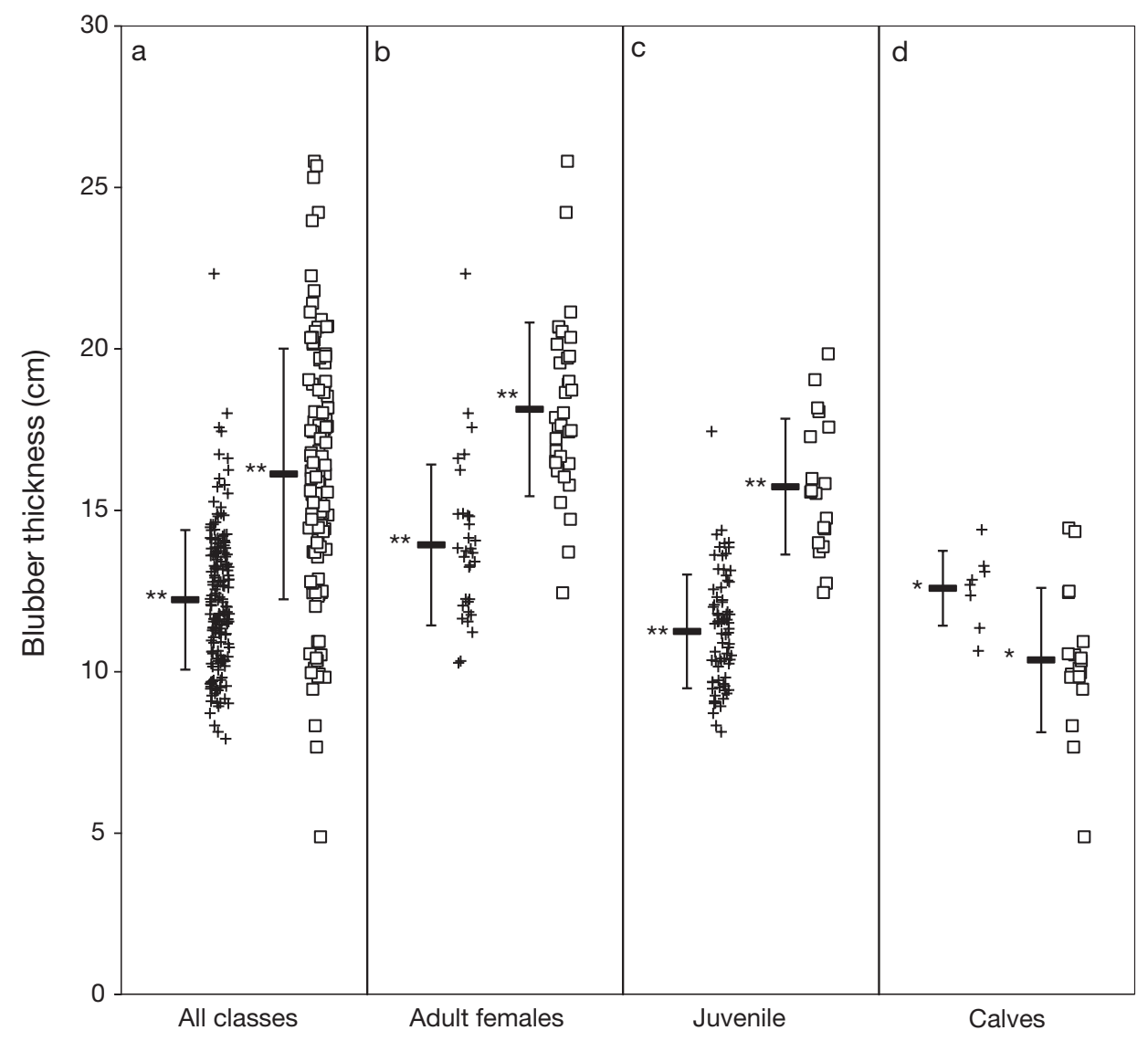

Fig. 9. Eubalaena glacialis (+) and Eubalaena australis ( $\square$ ). Blubber thickness measurements (randomly jittered with mean \pm 1 SD) collected by ultrasound from (a) all whales, (b) adult females, (c) juveniles, and (d) calves in the Bay of Fundy, Canada, from 1998 to 2002 and in St. Sebastian Bay, De Hoop Marine Reserve and Walker Bay (Gansbaai), South Africa from 1999 to 2000.

E. glacialis calves were 8 mo old, while E. australis calves were neonate to 4 mo old. ${ }^{*} \mathrm{p}<0.01,{ }^{* *} \mathrm{p}<0.0001$

\section{Eubalaena glacialis and Eubalaena australis}

Among lactating females, no difference was found between the blubber thickness of primiparous females (females that have had only 1 calf) and that of multiparous females (females that have had 2 or more calves) for E. australis (primiparous $18.78 \pm 2.69 \mathrm{~cm}, \mathrm{n}=9$; multiparous $18.15 \pm 3.06 \mathrm{~cm}, \mathrm{n}=17$; Smith-Satterthwaite $t$-test: $t_{18}=-0.538, \mathrm{p}=0.597$ ) or E. glacialis (primiparous $12.83 \pm 1.36 \mathrm{~cm}, \mathrm{n}=4$; multiparous $12.68 \pm 1.38 \mathrm{~cm}, \mathrm{n}=7$; 2-sample $t$-test: $\left.t_{9}=-0.174, \mathrm{p}=0.866\right)$.

\section{North Atlantic vs. South African right whale blubber thickness}

Blubber was significantly thinner in Eubalaena glacialis $(12.23 \pm 2.16 \mathrm{~cm}, \mathrm{n}=172)$ than in E. australis $(16.13 \pm 3.88 \mathrm{~cm}, \mathrm{n}=117)$ (Smith-Satterthwaite $t$-test: $t_{165,1}=-9.869, \mathrm{p}=0.000$; Fig. 9a). When the species were compared by age classes, E. glacialis blubber was significantly thinner than E. australis blubber for all age classes except calves: E. glacialis adult females $13.93 \pm 2.49 \mathrm{~cm}, \mathrm{n}=32$, E. australis adult females $18.13 \pm 2.69 \mathrm{~cm}, \mathrm{n}=35\left(t_{65}=-6.167, \mathrm{p}=0.000 ;\right.$ Fig. 9b); E. glacialis juveniles $11.25 \pm 1.76 \mathrm{~cm}, \mathrm{n}=75, \mathrm{E}$. australis juveniles $15.73 \pm 2.11 \mathrm{~cm}, \mathrm{n}=19\left(t_{25}=-8.549, \mathrm{p}=\right.$ 0.000; Fig. 9c). E. glacialis calves $(12.58 \pm 1.16 \mathrm{~cm}, \mathrm{n}=$ 8) were significantly fatter than $E$. australis calves $(10.36 \pm 2.24 \mathrm{~cm}, \mathrm{n}=18)\left(t_{23}=3.324, \mathrm{p}=0.003\right.$; Fig. 9d $)$, presumably because E. glacialis calves were approximately 5 to 7 mo older.

\section{DISCUSSION}

A combination of at-sea acoustic blubber thickness measurements and more than 2 decades of life history and reproductive data were used to assay body fat condition of 2 species of free-ranging right whales, Eubalaena glacialis in the North Atlantic and E. australis off the southern coast of South Africa. Adult females had the thickest blubber prior to pregnancy, calves showed a loss of blubber thickness after weaning, juveniles 
gained blubber thickness with length, males and yearlings had blubber thickness that varied with prey abundance, and E. australis had thicker blubber than E. glacialis. E. australis mothers were also shown to lose blubber thickness as their calves gained it during suckling.

Acoustic blubber thickness data from Eubalaena glacialis presented here (range $=8$ to $22 \mathrm{~cm}$ ) were comparable to ruler measurements of blubber thickness from along the dorsal midline at the level of the axilla collected during necropsy of E. glacialis (range = 8 to $17 \mathrm{~cm}$; Moore et al. 2004). E. australis acoustic blubber thickness data (range $=5$ to $26 \mathrm{~cm}$ ) were comparable to those reported during Soviet whaling (range $=5$ to $>30 \mathrm{~cm}$; Tormosov et al. 1998), where measurements were taken mid-laterally at the level of the anus. The difficulties inherent in measuring blubber thickness on carcasses often result in inconsistencies within and between data sets; therefore, comparisons within and between such data sets should be made with caution.

\section{Integument morphology and the acoustic assay}

Acoustic reflections from boundaries between materials of different acoustic impedances allow measurement of blubber thickness. Upon gross visual examination of the innermost aspect of Eubalaena glacialis integument (including the underlying skeletal muscle) collected at necropsy, Moore et al. (2001) described 2 tendinous connective tissue (CT) sheaths separated by loose CT. The distal sheath, described as the 'upper' sheath by Moore et al. (2001), occurred at the innermost aspect of the blubber while the proximal sheath, described as the 'lower' sheath, overlaid the skeletal muscle. The ultrasound examination of this same sample of integument from E. glacialis clearly showed acoustic reflections from both CT sheaths (Moore et al. 2001). The 2 sheaths are interconnected periodically and the distal sheath may not always be present. The proximal sheath is homologous to the SDS described in dolphins by Pabst (1996). In the sei whale Balaenoptera borealis, 2 'layers' (a 3 to $5 \mathrm{~mm}$ thick sheath comprised of elastic and collagen fibers and a region of dense collagenous bundles overlaying muscle) separated by well-vascularized adipose tissue interspersed with collagen fibers were observed in the innermost aspect of the blubber (Ackman et al. 1975). Also, Ackman et al. (1975) pointed out that according to Heyerdahl (1932), the 'isterlag' (a layer with elevated lipid content) was situated between 2 layers of connective tissue at the innermost aspect of fin and blue whale Balaenoptera musculus blubber. In bowhead whale Balaena mysticetus integument, Haldiman \& Tarpley
(1993) described a highly tendinous CT sheath (1 to $2 \mathrm{~mm}$ thick) bordering the innermost (deepest) part of the 'true' blubber (reticular dermis), which overlays a layer of loose CT containing varying amounts of adipose tissue (hypodermis), followed by the skeletal muscle. Haldiman \& Tarpley (1993) did not describe a second tendinous CT sheath (a proximal or 'lower' sheath) overlaying the skeletal muscle. The loose CT between the 2 CT sheaths described by Moore et al. (2001) is likely homologous to the hypodermis (loose CT layer) between the CT sheath and skeletal muscle described for bowhead whales, the region of well-vascularized adipose tissue layer observed in sei whales and the 'isterlag' observed in blue and fin whales. Our technology and analysis failed to consistently define a distal ('upper') sheath but was successful and consistent in acquiring reflections from the proximal sheath. As a result, the measurements of blubber thickness presented here include all tissue from the surface of the epidermis to the proximal CT sheath at the blubbermuscle interface.

The thick epidermis of cetaceans (Ling 1974) can vary by species (Simpson \& Gardiner 1972). Because the measurements presented here include epidermis, understanding the contribution of epidermis to the thickness of the entire integument for both Eubalaena glacialis and E. australis is important. Yet, the thickness of the epidermis could not be measured because the ultrasound was optimized for detecting structures (the tendinous CT sheath) deeper in the integument. Epidermis was measured on full-core biopsies of $E$. australis adults (mean $\pm 1 \mathrm{SE}=1.42 \pm 0.09 \mathrm{~cm}, \mathrm{n}=13$ ) and calves $(1.39 \pm 0.07 \mathrm{~cm}, \mathrm{n}=19)$ (Reeb et al. 2007) and on the body of E. glacialis at necropsy (1.1, 1.1, $1.2 \mathrm{~cm}$ for 3 whales; M. J. Moore unpubl. data). The measurements of epidermis from E. glacialis may appear thinner than measurements from biopsied $E$. australis because measurements from $E$. australis were not corrected for the angle of the biopsy (Reeb et al. 2007) and/or because measurements from E. glacialis could have experienced a variety of post-mortem deformations including compaction of the epidermis due to post-mortem rendering of the epidermal lipids, postmortem sloughing, the stresses and tension from the fibro-elastic integument being measured while attached to the body (whereas a measurement of a biopsy is free of such stresses and tensions), and/or the distribution of the whale's weight with respect to the location of measurement. However, based on the aforementioned epidermal thicknesses and the mean 'blubber thickness' (integument thickness) for each right whale species, epidermis only accounts for a small proportion of the entire thickness of the integument. Any difference in epidermal thicknesses between the 2 species is likely to be on the scale of a few millimeters or less. 
Therefore, the thickness of the epidermis most likely does not make a sizeable contribution to any differences in thickness of the integument presented here. As such, the observed differences in ultrasound 'blubber thickness' measurements are driven primarily by changes in dermal and/or hypodermal thickness.

The blubber of large whales is not metabolized as a whole (Castellini 2000), but rather lipids are deposited to or mobilized from adipocytes, which are supported by a matrix of collagen. In several other cetaceans, trends in blubber lipid content (either measured directly or inferred from adipocyte morphology) parallel trends in blubber thickness with respect to reproductive (adult females) and nutritive status (Lockyer 1981, 1986, 1987, Aguilar \& Borrell 1990, Koopman et al. 2002). In Eubalaena australis mothers, changes in blubber lipid composition (Reeb 2001) paralleled the observed thinning of blubber (Fig. 4) during the initial months of lactation. Such evidence suggests that variability in lipid content and composition contributed to the changes and differences in blubber thickness presented here. Moreover, lipid content and composition of blubber can vary both across the body and with depth from the epidermis in cetaceans, which has led to the hypothesis that certain areas and blubber depths are more metabolically active than others (e.g. Ackman et al. 1975, Lockyer et al. 1984, Aguilar \& Borrell 1990, Koopman 2007). Although such variability in blubber lipids across the body and with depth from the epidermis needs to be determined in right whales, the measurements of 'blubber' thickness presented here includes all tissue from the surface of the epidermis to the proximal $\mathrm{CT}$ sheath at the blubber-muscle interface, thus integrating the entire integumentary energy store.

\section{Blubber thickness and body length}

Positive linear relationships between blubber thickness and body length were found in fin and blue whales (Nishiwaki \& Hayashi 1950, Nishiwaki \& Oye 1951), while a negative relationship was observed in harbor porpoise Phocoena phocoena (Koopman 1998). Blubber thickness and body length were not related in gray whales Eschrichtius robustus (Rice \& Wolman 1971). Tormosov et al. (1998) plotted a positive linear relationship between blubber thickness and body length in Eubalaena australis taken by Soviet whaling operations. Blubber thickness and body length were not related in E. glacialis when all data were analyzed together (Fig. 2). However, when the life history stages were analyzed separately, blubber thickness significantly increased with increasing body length in juveniles and unknown age whales. Interestingly, by visualizing this strong relationship in juvenile and unknown age whales with the data from other life history stages (Fig. 2), the relationship for all whales combined may have been skewed by calves having thicker blubber and lactating females having thinner blubber than expected for their respective body lengths.

\section{Blubber thickness and nutritional regime}

In Eubalaena australis calves of the South African population, blubber thickness increased significantly during the initial months of suckling (Fig. 4a), a time during which rapid growth in length occurs, $2.8 \pm$ $0.7 \mathrm{~cm} \mathrm{~d}^{-1}$ (Best \& Rüther 1992). The blubber of $E$. glacialis calves measured in the late months of suckling was as thick as older juvenile whales ( 7 and $8 \mathrm{yr}$ old whales) and much thicker than the younger juveniles (Fig. 3a). The substantially thicker blubber of calves suggests that the mother's milk provides right whale calves with a positive energy balance, allowing storage of lipids in the blubber while simultaneously growing in length at a rapid rate.

Significant thickening of blubber during suckling reversed to a significant thinning once the calves were weaned (Fig. 3). Weaning appears to occur typically at approximately 10 to 12 mo of age (Hamilton et al. 1995, Hamilton \& Cooper 2010). Similarly in harbor porpoise, blubber thickness decreased from calves to adults, with the greatest relative decline occurring immediately after weaning (Koopman 1998). Effects of weaning, such as interruptions in the growth curve, have been observed in other mammalian species (Pond 1977). A post-weaning hiatus in growth of body length appeared to occur in juvenile bowhead whales (Lubetkin et al. 2008) and in juvenile Eubalaena australis (Best \& Schell 1996). The post-weaning thinning of blubber is likely an indication that young right whale juveniles rely on the lipids in their blubber to help support energetic challenges as they transition to nutritional independence.

The principal prey species of Eubalaena glacialis is the later stages of the copepod Calanus finmarchicus (Kenney et al. 1986, Baumgartner \& Mate 2003, Michaud \& Taggart 2007), the abundance of which can be highly variable, both seasonally and annually, and appears to be influenced by climate (Conversi et al. 2001, Greene et al. 2003, Pershing et al. 2005). Right whales must find prey patches dense enough for feeding to be energetically efficient (Kenney et al. 1986, Baumgartner \& Mate 2003, Michaud \& Taggart 2007) because they are essentially ram filter feeders without the ability to concentrate prey (Baumgartner et al. 2007). Differences in blubber thickness of adult males and yearlings were detected among years during 
which C. finmarchicus abundance in the GoM fluctuated greatly (Pershing et al. 2005) (Fig. 5). In 1998, C. finmarchicus abundance in the GoM declined to the third lowest value of the entire Pershing et al. (2005) time series (1961-1974, 1978-2003). In 1999 and 2000 C. finmarchicus abundance in the GoM recovered relative to 1998 but was still below the Pershing et al. (2005) time series average. Notably, blubber thickness of adult male E. glacialis mirrored C. finmarchicus abundance in these years; it was significantly thinner in 1998 when compared with 1999 and 2000 (Fig. 5). C. finmarchicus abundance in the GoM (Pershing et al. 2005) then increased to above average values in 2001 and 2002, but only one adult male was measured in each of these years.

Likewise, yearlings measured in 1998 had significantly thinner blubber than those measured in 2002, the year of the second highest Calanus finmarchicus abundance in the GoM (Pershing et al. 2005) of our study period (Fig. 5). As discussed above, the significant thinning of blubber thickness between calf and yearling Eubalaena glacialis suggests that the transition to nutritional independence is energetically challenging. For the 1998 yearlings, this already challenging transition likely was intensified by the dramatically low abundance of $C$. finmarchicus. Furthermore, the 1998 yearlings may have been weaned earlier than the 2002 yearlings; many of the 2002 yearlings were sighted in close association with their mothers well into their second year of life, a phenomenon which rarely has been observed in E. glacialis and may indicate that suckling was prolonged for the 2002 yearlings (Hamilton \& Cooper 2010). Nutrition in early postnatal life, particularly prior to weaning, influences the number of adipocytes and total adiposity, as observed in woodchucks (Young 1976) and rats (Knittle \& Hirsch 1968). As such, the thicker blubber of the 2002 yearlings may have been indicative of better nutrition, whether the result of greater availability of $C$. finmarchicus during the transition to nutritional independence and/or prolonged suckling.

\section{Blubber thickness and reproduction}

Female mammals, particularly from those species that fast during portions of the reproductive cycle, can increase their chances of reproductive success by acquiring adequate fat reserves to ensure survival of themselves and healthy offspring. The mechanism for this appears to occur prior to the start of the reproductive cycle; ample reserves of body fat are necessary for ovulation to occur (e.g. Doney et al. 1982, Frisch 1984, Albon et al. 1986) because sufficient levels of leptin, the hormone produced by adipose tissue that is correlated with adipose tissue mass (see Houseknecht et al. 1998, Chilliard et al. 2005 for reviews), are necessary for successful reproduction (see Zieba et al. 2005, Barb et al. 2008, Hill et al. 2008 for reviews). Leptin appears to serve as the primary metabolic signal linking energy status with the neuroendocrine system and subsequent reproduction (see Houseknecht et al. 1998, Zieba et al. 2005, Barb et al. 2008, Hill et al. 2008 for reviews). Through a complex process involving an array of neuroendocrine and endocrine signals, leptin acts on the hypothalamus and pituitary to stimulate the release of $\mathrm{GnRH}$ and $\mathrm{LH}$, respectively (see Zieba et al. 2005, Barb et al. 2008, Hill et al. 2008 for reviews), thereby influencing ovulation and subsequent reproduction.

Given the importance of body fat and nutritional status to mammalian reproduction, particularly with regards to ovulation, the finding that adult females measured prior to the start of pregnancy had the thickest blubber of all life history classes in Eubalaena glacialis is noteworthy (Fig. 6). Also, the blubber of an individual female increased by $4.2 \mathrm{~cm}$ during the year leading up to the start of pregnancy (Fig. 7). In balaenopterids, pregnant females had the thickest blubber (Lockyer 1981, 1987) and the highest blubber lipid content (Lockyer 1987, Aguilar \& Borrell 1990) of all age classes but peri-ovulatory females were not specified. Body fat condition data from prior to the potential start of pregnancy appear to exist for only one other species of large whale. The blubber of female gray whales that had recently ovulated was thicker than that of immature males and females, adult males, and adult anoestrous and postpartum females, but similar in thickness to that of females taken during the early and late stages of pregnancy (Rice \& Wolman 1971). Based on these results, in which improved body condition was apparent prior to the start of pregnancy (right whales) and peri-ovulatory and during gestation (gray whales), and the preponderance of evidence in this respect from other mammals, body fat appears to play a critical, and possibly permissive, role in the initiation of the large whale reproductive cycle. The significant thickening of blubber prior to the start of pregnancy suggests that, like terrestrial mammals, a critical level of body fat appears to be important for successful ovulation and subsequent reproduction in right whales.

Hlista et al. (2009) observed a significant positive relationship between the number of right whale calves born each year between 1998 and 2007 (an indicator of reproductive success) and a weighted annual chlorophyll concentration (a realization of a right whale nutritional index based on concentrations coinciding with peak right whale sightings in high-use habitats) averaged over the prior $2 \mathrm{yr}$, the significance of which appeared to be driven primarily by the strong relation- 
ship between annual right whale calf counts and weighted annual chlorophyll concentrations from $2 \mathrm{yr}$ prior. Such relationships concur with the hypothesis that high-quality feeding conditions in the year leading up to conception likely lead to substantial accumulation of blubber lipid reserves (as indicated by the thickest blubber observed in pre-pregnant females), subsequently affecting calf production through the short and long term metabolic cues necessary for successful reproductive function (e.g. Prunier \& Quesnel 2000, Barb et al. 2008, Hill et al. 2008).

As mentioned above, pregnant balaenopterids and peri-ovulatory and pregnant gray whales had the thickest blubber of all life history classes in these species (Rice \& Wolman 1971, Lockyer 1981, 1987). Moreover, the similarity in blubber thickness among peri-ovulatory, early pregnant and late pregnant gray whales (Rice \& Wolman 1971) suggests that the blubber thickness of gray whale females does not change between ovulation and late gestation. The lack of relationship between annual calf count and weighted annual chlorophyll concentration from 1 yr prior (Hlista et al. 2009) may indicate that feeding conditions during gestation are not as critical to calf production as those leading up to conception. Having measured only one pregnant right whale, further study is necessary to examine such trends during gestation in right whales.

In other large whales, lactation was calculated as the costliest part of the reproductive cycle (Lockyer 1981), and in other mammals, lactation was estimated to require 3 to 5 times more energy than gestation (Young 1976). Much of these energetic costs of lactation likely occur during the initial months; right whale mothers do not appear to feed while on the calving grounds and consequently are believed to support their calves and themselves during these months by relying on endogenous nutrient reserves-a concept supported by these results. Blubber thickness decreased significantly between the second month of lactation (September 1999) and the fourth month (November 2000) among lactating Eubalaena australis females (Fig. 4b). Likewise, when individual E. australis mothers were measured on multiple occasions within the same calving season, dorsal body shape (determined by a series of aerial photogrammetric measurements of body width) thinned significantly during the initial months of lactation (C. A. Miller unpubl. data), suggesting that the difference in blubber thickness was due to lactation rather than an inter-annual difference in blubber thickness. Corresponding to this significant thinning of blubber during the initial months of lactation, Reeb (2001) detected a significant change in blubber fatty acid composition in lactating E. australis mothers between these same months (September 1999 and November 2000), not only suggesting that lipids in right whale blubber are affected by lactation but also supporting the assertion that the thinning of blubber during lactation likely is a result of catabolism of blubber lipids.

Among the resting Eubalaena glacialis females, blubber thickness was positively related to the number of years since the last calving event, suggesting recovery and replenishment of body fat reserves during the time between calves (Fig. 8). Right whale females are capable of a 3 yr calving interval (Knowlton et al. 1994, Best et al. 2001, Kraus et al. 2007): 1 yr of gestation, 1 yr of lactation, and $1 \mathrm{yr}$ of recovery. Considering that the greatest difference in blubber thickness was observed between females that had been lactating for 8 mo and those measured a few months prior to the start of gestation, right whale females would need to encounter enough food not only to cover daily metabolic needs but also to replenish lipid stores during the year of recovery. If right whale females do not encounter an adequate food supply, the replenishment of body fat reserves may slow and increases in calving interval may occur. For example, in primiparous pigs, a longer weaning to first oestrus interval was observed in sows with lower backfat as compared to sows with higher backfat (Tummaruk et al. 2001). Moreover, nutritional status is not only important to the replenishment of fat reserves but also can affect reproductive performance. For instance, chronic feed restriction interfered with normal cyclicity in the pig where ovarian activity was altered through the alteration of hypothalamic release of GnRH (Armstrong \& Britt 1987). In this regard, it is interesting to note that a significant increase in calving interval among E. glacialis from 3.67 yr (1987 to 1992) to greater than 5 yr (1993 to 1998) (Kraus et al. 2001) paralleled to changes in Calanus finmarchicus abundance in the GoM, which was low throughout the 1990 s relative to the late 1980 s when abundance was at its highest (Pershing et al. 2005).

In Eubalaena glacialis, the blubber thickness of nulliparous females was significantly thinner than that of pre-pregnant females but not statistically different from the energetically drained lactating females (Fig. 6). A few of the nulliparous females that were measured during this study subsequently produced calves, including E. glacialis no. 2050, whose blubber increased by more than $4 \mathrm{~cm}$ in the year leading up to the start of pregnancy (see next paragraph). As of $2005,12 \%$ of adult E. glacialis females were reproductively inactive (Kraus et al. 2007), which in part, as our results suggest, may be a consequence of females not attaining adequate body fat reserves necessary for successful reproduction.

Four individual Eubalaena glacialis females were measured in multiple years at different stages in their reproductive cycles (Fig. 7). These measurements offer evidence that annual changes in blubber thickness of 
individual whales are detectable and serve to corroborate our population-based results. In particular, the series of measurements from E. glacialis no. 2050 highlight that blubber thickness changes among reproductive stages can be marked. E. glacialis no. 2050 was thinnest as a nulliparous female when measured in 1998, when Calanus finmarchicus abundance in the GoM (Pershing et al. 2005) was dramatically low. One year later as pre-pregnant, her blubber was $4.2 \mathrm{~cm}$ thicker, the thickest measurement collected during the series. She was not measured the next year during gestation but was measured again the following year after 8 mo of lactation. Blubber thickness decreased by $3.4 \mathrm{~cm}$ between the pre-pregnant measurement and the measurement collected after 8 mo of lactation.

The mean blubber thickness of adult male Eubalaena glacialis was similar to that of older juveniles and lactating, resting, and nulliparous adult females (Fig. 6). Mean adult male blubber thickness was affected by the thin blubber measurements collected from males in 1998, but the mean blubber thicknesses of males in 1999 and 2000 were essentially the same as that of nulliparous females (see 'Results'). In human males, weight loss and low body fat may result in decreased sperm mobility and longevity, decreased hypothalamic GnRH, and decreased levels of testosterone and prolactin in blood serum levels (see Frisch 1997 for review). Such interactions between body fat and fertility may be mediated by the hormone leptin. In bulls, rams, boars and stallions, malnutrition was associated with decreases in spermatogenesis (Foote 1978). Given that male right whales have the largest testes among the baleen whale species, both in absolute weight and relative to body weight (Brownell \& Ralls 1986) and are believed to use sperm competition as a mating strategy (Brownell \& Ralls 1986, Kraus \& Hatch 2001), sexual activity may be energetically costly for male right whales. Male blubber thickness and body fat condition should therefore, in the future, be analyzed in the context of paternity.

\section{North Atlantic vs. South African right whale blubber thickness}

When reproductive parameters of the Eubalaena glacialis population were compared with those of the E. australis populations, E. glacialis reproduction appears to be much more variable and at times compromised (see 'Introduction'). In this regard, the finding that blubber thickness, measured during a depressed time in E. glacialis reproduction (Kraus et al. 2007), was significantly thinner than in E. australis of the South African population is interesting (Fig. 9). The difference in blubber thickness remained significant when the species were compared within age classes except for the comparison between calves (Fig. 9d), where E. glacialis calves had thicker blubber because they were approximately 3 to 9 mo older than the $E$. australis calves.

The observed difference in blubber thickness between Eubalaena glacialis and E. australis could be explained by differences in body size, measurement season, habitat temperature regime, genetics, or levels of nutrition. Whales belonging to these 2 species appear to be comparable in size (Best \& Rüther 1992, W. L. Perryman pers. comm.), but without measurements of total length from the individuals for which measurements of blubber thickness were collected, testing whether or not differences in total length influenced the observed difference in blubber thickness was not possible.

Eubalaena glacialis blubber was measured during the summer feeding season while E. australis was measured during the winter breeding season. In balaenopterid whales, blubber thickens during the summer feeding season and thins during the winter migration (see Lockyer 1981 for review). Summer seasonal fattening was not detected in measurements of blubber thickness in southern right whales taken by whaling (Tormosov et al. 1998). Such fattening may not have been detected due to pooling the data over a $6 \mathrm{yr}$ period (Tormosov et al. 1998), differences in individual whale arrival times to the feeding grounds (e.g. Lockyer 1981, Lockyer et al. 1985), inter-annual differences in prey abundance or in seasonality of prey abundance, or limited seasonal coverage (no winter measurements were available). However, our results indicate that the thickness of right whale blubber can change seasonally in lactating females and annually depending on nutritional and reproductive status. If seasonal fattening and thinning does occur in right whales, everything else being equal, measurements of blubber thickness from E. glacialis collected during summer feeding should be greater than those from $E$. australis collected during winter fasting, minimizing what would have been an even larger difference had the seasons been comparable.

Right whales experience a wide range of water temperatures on a daily (between surface and depth) and seasonal basis (between subtropical and temperate waters); therefore, the only plausible way temperature could have contributed to the inter-species difference in blubber thickness was if the overall habitat temperature regime differed. For example, if the overall temperature range experienced by Eubalaena australis was consistently lower than that experienced by $E$. glacialis, it is possible that E. australis had thicker blubber necessary for insulation against the colder 
temperatures. Equally, it is possible that right and other large whales are constrained by the need to lose heat (Alexander 1998).

Analysis of genetic markers from both mitochondrial (Rosenbaum et al. 2000) and nuclear DNA (Gaines et al. 2005) indicate that right whales of the North Atlantic and of the Southern Hemisphere are 2 distinct species, Eubalaena glacialis and E. australis respectively. Genetic factors controlling fat storage and/or utilization may affect the observed difference in blubber thickness between the 2 species.

Finally, the difference in blubber thickness between the 2 species could be influenced by differing levels of nutrition. Both species feed on lipid-rich, late stage calanoid copepods (Kenney et al. 1986, Tormosov et al. 1998, Baumgartner \& Mate 2003, Michaud \& Taggart 2007); southern right whales also feed on euphausiids (Hamner et al. 1988, Tormosov et al. 1998, Reeb 2001). Prey species, life stage, available biomass and patch density will impact relative foraging success; therefore, in aggregate, southern right whales appear to be more successful at accumulating energy reserves.

Although further investigation is needed to fully understand the observed difference in blubber thickness between Eubalaena glacialis of the North Atlantic and E. australis of the southern coast of South Africa, the difference is suggestive in the context of the differences in reproductive performance of the 2 species. According to our results, adequate food supply appears to be necessary for adequate body fat reserves which, in turn, appear to be necessary for successful reproduction in right whales. Therefore, the thicker blubber of $E$. australis, which may indicate a better nutritional regime, likely contributes to the more successful and stable reproductive performance of this population, where the population growth rate is close to the maximum biologically possible.

Acknowledgements. We thank all those who assisted with field work: M. S. Morss, J. N. Ciano, M. K. Marx, P. K. Hamilton, L. A. Conger, C. K. Slay, S. D. Kraus, B. M. McKay, J. N. Wocial, T. R. Frasier, C. J. Harper, M. Levine, L. Morse, O. Nichols, M. Piche, B. Bjermi, H. T. C. Moore and the Moore family, M. Best, M. Thornton, A. Du Randt, D. Kemp, M. Addison, and D. P. Nowacek, A. Shorter and the WHOI D-tag project. We thank the New England Aquarium Right Whale Research Project for field support, matching of the individual whales and the creation and ongoing maintenance of the right whale database. The Right Whale Consortium generously granted access to the right whale database; v. 29 June 2004 was used. S. Berube and D. Kass of Panametrics assisted with the ultrasound equipment. K. Prada, Upper Cape Systems created the software to acquire and record the ultrasound data. B. Lange and D. Wright made possible the video documentation of the blubber thickness measurements. Mazda Wildlife Fund provided invaluable vehicle support in South Africa. W. L. Perryman generously shared total length data. G. Terray, A. Solow and A. Beet assisted with data extraction. We thank M. F. Baumgartner and A. J. Pershing for discussions about right whale prey, body condition and reproduction. R. Asmutis-Silvia worked on the development of the project in the early years. We also acknowledge 4 anonymous reviewers whose thorough efforts significantly improved the manuscript. Acoustic blubber measurements of Eubalaena glacialis were collected under license numbers 1999-026, 2000-014, 2001-020, and 2002-029 from the Canadian Department of Fisheries and Ocean and National Marine Fisheries Service permit number 1014 to S. D. Kraus. Measurements of $E$. australis were collected under permits to P.B.B. from the South African Department of Environment Affairs and Tourism. This project was made possible with funds provided by Massachusetts Environmental Trust, Office of Naval Research, National Marine Fisheries Service-National Oceanic and Atmospheric Administration, Northeast Consortium, Hussey Foundation, and National Research Foundation in South Africa.

\section{LITERATURE CITED}

Ackman RG, Hingley JH, Eaton CA, Sipos JC, Mitchell ED (1975) Blubber fat deposition in mysticeti whales. Can J Zool 53:1332-1339

Aguilar A, Borrell A (1990) Patterns of lipid content and stratification in the blubber of fin whales (Balaenoptera physalus). J Mammal 71:544-554

> Albon SD, Mitchell B, Huby BJ, Brown D (1986) Fertility in female red deer (Cervus elaphus): the effects of body composition, age and reproductive status. J Zool 209:447-460

Alexander RM (1998) All-time giants: the largest animals and their problems. Palaeontology 41:1231-1245

Armstrong JD, Britt JH (1987) Nutritionally-induced anestrus in gilts: metabolic and endocrine changes associated with cessation and resumption of estrous cycles. J Anim Sci 65: 508-523

Barb CR, Hausman GJ, Lents CA (2008) Energy metabolism and leptin: effects on neuroendocrine regulation of reproduction in the gilt and sow. Reprod Domest Anim 43:324-330

$>$ Baumgartner MF, Mate BR (2003) Summertime foraging ecology of North Atlantic right whales. Mar Ecol Prog Ser 264: 123-135

Baumgartner MF, Mayo CA, Kenney RD (2007) Enormous carnivores, microscopic food, and a restaurant that's hard to find. In: Kraus SD, Rolland RM (eds) The urban whale: North Atlantic right whales at the crossroads. Harvard University Press, Cambridge, MA, p 138-171

Best PB (1990) Natural markings and their use in determining calving intervals in right whales off South Africa. S Afr J Zool 25:114-123

Best PB (1994) Seasonality of reproduction and the length of gestation in southern right whales Eubalaena australis. J Zool 232:175-189

- Best PB, Rüther H (1992) Aerial photogrammetry of southern right whales, Eubalaena australis. J Zool 228:595-614

> Best PB, Schell DM (1996) Stable isotopes in southern right whale (Eubalaena australis) baleen as indicators of seasonal movements, feeding and growth. Mar Biol 124:483-494

Best PB, Brandão A, Butterworth DS (2001) Demographic parameters of southern right whales off South Africa. J Cetacean Res Manag Spec Issue 2:161-169

$>$ Bickel DR (2002) Robust estimators of the mode and skewness of continuous data. Comput Stat Data Anal 39:153-163

> Brown MW, Kraus SD, Gaskin DE, White BN (1994) Sexual composition and analysis of reproductive females in the North Atlantic right whale, Eubalaena glacialis, population. Mar Mamm Sci 10:253-265

Brownell RL, Ralls K (1986) Potential for sperm competition in 
baleen whales. Rep Int Whaling Comm Spec Issue 8:97-112 Castellini M (2000) History of polar whaling: insights into the physiology of the great whales. Comp Biochem Physiol A 126:153-159

Chilliard Y, Delavaud C, Bonnet M (2005) Leptin expression in ruminants: nutritional and physiological regulations in relation with energy metabolism. Domest Anim Endocrinol 29:3-22

Conversi A, Piontkovski S, Hameed S (2001) Seasonal and interannual dynamics of Calanus finmarchicus in the Gulf of Maine (Northeastern US shelf) with reference to the North Atlantic Oscillation. Deep-Sea Res II 48:519-530

Cooke JG, Rowntree VJ, Payne R (2001) Estimates of demographic parameters for southern right whales (Eubalaena australis) observed off Península Valdés, Argentina. J Cetacean Res Manag Spec Issue 2:125-132

Curran MP, Asher WM (1974) Investigation of blubber thickness in a gray whale using ultrasonography. Mar Fish Rev $36: 15-20$

Devore JL (1995) Probability and statistics for engineering and the sciences, 4th edn. Duxbury Press, Pacific Grove, CA

Doidge DW (1990) Integumentary heat loss and blubber distribution in the beluga, Delphinapterus leucas, with comparisons to the narwhal, Monodon monoceros. Can Bull Fish Aquat Sci 224:129-140

Doney JM, Gunn RG, Horak F (1982) Reproduction. In: Coop IE (ed) Sheep and goat production. Elsevier Scientific, Amsterdam, p 57-80

> Dunkin RC, McLellan WA, Blum JE, Pabst DA (2005) The ontogenetic changes in the thermal properties of blubber from Atlantic bottlenose dolphin Tursiops truncatus. J Exp Biol 208:1469-1480

> Dunkin RC, McLellan WA, Blum JE, Pabst D (2010) The buoyancy of the integument of Atlantic bottlenose dolphins (Tursiops truncatus): effects of growth, reproduction, and nutritional state. Mar Mamm Sci 26:573-587

Foote RH (1978) Factors influencing the quantity and quality of semen harvested from bulls, rams, boars and stallions. J Anim Sci 47:1-11

Frisch RE (1984) Body fat, puberty and fertility. Biol Rev Camb Philos Soc 59:161-188

Frisch R (1997) Body weight, body fat and ovulation: relation to the natural fertility of populations. In: Dorfman R, Rogers P (eds) Science with a human face: in honor of Roger Randall Revelle. Harvard University Press, Cambridge, MA, p 139-166

Gaines CA, Hare MP, Beck SE, Rosenbaum HC (2005) Nuclear markers confirm taxonomic status and relationships among highly endangered and closely related right whale species. Proc R Soc Lond B Biol Sci 272:533-542

Gales NJ, Burton HR (1987) Ultrasonic measurement of blubber thickness of the southern elephant seal, Mirounga leonina (Linn). Aust J Zool 35:207-217

Greene $\mathrm{CH}$, Pershing AJ, Conversi A, Planque B, and others (2003) Trans-Atlantic responses of Calanus finmarchicus populations to basin-scale forcing associated with the North Atlantic Oscillation. Prog Oceanogr 58:301-312

Haldiman JT, Tarpley RJ (1993) Anatomy and physiology. In: Burns JJ, Montague JJ, Cowles CJ (eds) The bowhead whale. Society for Marine Mammalogy, Spec Publ 2. Allen Press, Lawrence, KS, p 71-156

Hamilton PK, Cooper LA (2010) Changes in North Atlantic right whale (Eubalaena glacialis) cow-calf association times and use of the calving ground: 1993-2005. Mar Mamm Sci 26:896-916

> Hamilton PK, Marx MK, Kraus SD (1995) Weaning in North Atlantic right whales. Mar Mamm Sci 11:386-390
Hamilton PK, Knowlton AR, Marx MK, Kraus SD (1998) Age structure and longevity in North Atlantic right whales Eubalaena glacialis and their relation to reproduction. Mar Ecol Prog Ser 171:285-292

Hamilton JL, Dillaman RM, McLellan WA, Pabst DA (2004) Structural fiber reinforcement of keel blubber in harbor porpoise (Phocoena phocoena). J Morphol 261:105-117

Hamilton PK, Knowlton AR, Marx MK (2007) Right whales tell their own stories: the photo-identification catalog. In: Kraus SD, Rolland RM (eds) The urban whale: North Atlantic right whales at the crossroads. Harvard University Press, Cambridge, MA, p 75-104

Hamner WM, Stone GS, Obst BS (1988) Behavior of southern right whales, Eubalaena australis, feeding on the Antarctic krill, Euphausia superba. Fish Bull 86:143-150

Heyerdahl EF (1932) Hvalindustrien. En teknisk-kjemisk undersøkelse I Råmaterialet, Publ 7. Kommandør Chr. Christensens Hvalfangstmuseum, Sandefjord

Hill JW, Elmquist JK, Elias CF (2008) Hypothalamic pathways linking energy balance and reproduction. Am J Physiol Endocrinol Metab 294:E827-E832

Hlista BL, Sosik HM, Martin Traykovski LV, Kenney RD, Moore MJ (2009) Seasonal and interannual correlations between right-whale distribution and calving success and chlorophyll concentrations in the Gulf of Maine, USA. Mar Ecol Prog Ser 394:289-302

- Houseknecht KL, Baile CA, Matteri RL, Spurlock ME (1998) The biology of leptin: a review. J Anim Sci 76:1405-1420

International Whaling Commission (2001) Report of the workshop on status and trends of western North Atlantic right whales. J Cetacean Res Manag Spec Issue 2:61-87

International Whaling Commission (2006) Report of the scientific committee. J Cetacean Res Manag 8:1-65

IUCN (International Union for Conservation of Nature) (2008) 2008 IUCN red list of threatened species. www.iucnred list.org (Accessed 16 Mar 2011)

Kenney RD, Hyman MAM, Owen RE, Scott GP, Winn HE (1986) Estimation of prey densities required by western North Atlantic right whales. Mar Mamm Sci 2:1-13

Kipps EK, McLellan WA, Rommel SA, Pabst DA (2002) Skin density and its influence on buoyancy in the manatee (Trichechus manatus latirostris), harbor porpoise (Phocoena phocoena), and bottlenose dolphin (Tursiops truncatus). Mar Mamm Sci 18:765-778

Knittle JL, Hirsch J (1968) Effect of early nutrition on the development of rat epididymal fat pads: cellularity and metabolism. J Clin Invest 47:2091-2098

Knowlton AR, Kraus SD (2001) Mortality and serious injury of northern right whales (Eubalaena glacialis) in the western North Atlantic Ocean. J Cetacean Res Manag Spec Issue 2: 193-208

Knowlton AR, Kraus SD, Kenney RD (1994) Reproduction in North Atlantic right whales (Eubalaena glacialis). Can J Zool 72:1297-1305

Koopman HN (1998) Topographical distribution of the blubber of harbor porpoises (Phocoena phocoena). J Mammal 79: 260-270

> Koopman HN (2007) Phylogenetic, ecological, and ontogenetic factors influencing the biochemical structure of the blubber of odontocetes. Mar Biol 151:277-291

> Koopman HN, Pabst DA, McLellan WA, Dillaman RM, Read AJ (2002) Changes in blubber distribution and morphology associated with starvation in the harbor porpoise (Phocoena phocoena): evidence for regional differences in blubber structure and function. Physiol Biochem Zool 75:498-512

Kraus SD, Hatch JJ (2001) Mating strategies in the North Atlantic right whale (Eubalaena glacialis). J Cetacean Res 
Manag Spec Issue 2:237-244

Kraus SD, Hamilton PK, Kenney RD, Knowlton A, Slay C (2001) Reproductive parameters of the North Atlantic right whale. J Cetacean Res Manag Spec Issue 2:231-236

Kraus SD, Brown MW, Caswell H, Clark CW and others (2005) North Atlantic right whales in crisis. Science 309:561-562

Kraus SD, Pace RM, Frasier TR (2007) High investment, low return: the strange case of reproduction in Eubalaena glacialis. In: Kraus SD, Rolland RM (eds) The urban whale: North Atlantic right whales at the crossroads. Harvard University Press, Cambridge, MA, p 172-199

Ling JK (1974) The integument of marine mammals. In: Harrison RJ (ed) Functional anatomy of marine mammals, Vol 2. Academic Press, New York, NY, p 1-44

Lockyer C (1981) Growth and energy budgets of large baleen whales from the Southern Hemisphere. In: FAO Advisory Committee on Marine Resource Research (eds) Mammals in the Sea, Vol 3. General papers and large cetaceans. FAO, Rome, p 379-488

Lockyer C (1986) Body fat condition in Northeast Atlantic fin whales, Balaenoptera physalus, and its relationship with reproduction and food resource. Can J Fish Aquat Sci 43: 142-147

Lockyer C (1987) The relationship between body fat, food resource and reproductive energy costs in north Atlantic fin whales (Balaenoptera physalus). Symp Zool Soc Lond 57: 343-361

Lockyer C (1991) Body composition of the sperm whale, Physeter catodon, with special reference to the possible functions of fat depots. Rit Fiskideildar 12:1-24

> Lockyer CH, McConnell LC, Waters TD (1984) The biochemical composition of fin whale blubber. Can J Zool 62: 2553-2562

> Lockyer CH, McConnell LC, Waters TD (1985) Body condition in terms of anatomical and biochemical assessment of body fat in North Atlantic fin and sei whales. Can J Zool 63: 2328-2338

Lubetkin SC, Zeh JE, Rosa C, George JC (2008) Age estimation for young bowhead whales (Balaena mysticetus) using annual baleen growth increments. Can J Zool 86:525-538

McEvoy TG, Robinson JJ (2003) Nutrition and its interaction with reproductive processes. In: Holt WV, Pickard AR, Rodger JC, Wildt DE (eds) Reproductive science and integrated conservation. Cambridge University Press, Cambridge, p 42-56

Michaud J, Taggart CT (2007) Lipid and gross energy content of North Atlantic right whale food, Calanus finmarchicus, in the Bay of Fundy. Endang Species Res 3:77-94

Miller Angell C (2006) Body fat condition of free-ranging right whales, Eubalaena glacialis and Eubalaena australis. PhD dissertation, Boston University, Boston, MA

Moore MJ, Miller CA, Morss MS, Arthur R and others (2001) Ultrasonic measurement of blubber thickness in right whales. J Cetacean Res Manag Spec Issue 2:301-309

Moore MJ, Knowlton AR, Kraus SD, McLellan WA, Bonde RK (2004) Morphometry, gross morphology and available histopathology in North Atlantic right whale (Eubalaena glacialis) mortalities (1970-2002). J Cetacean Res Manag 6: 199-214

Nishiwaki M, Hayashi K (1950) Biological survey of fin and blue whales taken in the Antarctic season $1947-48$ by the Japanese fleet. Sci Rep Whales Res Inst Tokyo 3:132-190

Nishiwaki M, Oye T (1951) Biological investigation on blue whales (Balaenoptera musculus) and fin whales (Balaenoptera physalus) caught by the Japanese Antarctic whaling fleets. Sci Rep Whales Res Inst Tokyo 5:91-167

NOAA (National Oceanic and Atmospheric Administration)
(2009) Stock assessment report: North Atlantic right whale (Eubalaena glacialis): Western Atlantic stock. www. nmfs.noaa.gov/pr/pdfs/sars/ao2009whnr-w.pdf (Accessed 6 Nov 2010)

Omura H, Ohsumi S, Nemoto T, Nasu K, Kasuya T (1969) Black right whales in the North Pacific. Sci Rep Whales Res Inst Tokyo 21:1-78

Pabst DA (1996) Morphology of the subdermal connective tissue sheath of dolphins: a new fibre-wound, thin-walled, pressurized cylinder model for swimming vertebrates. J Zool 238:35-52

Pershing AJ, Greene CH, Jossi JW, O'Brien L, Brodziak JKT, Bailey BA (2005) Interdecadal variability in the Gulf of Maine zooplankton community, with potential impacts on fish recruitment. ICES J Mar Sci 62:1511-1523

> Pershing AJ, Head EHJ, Greene CH, Jossi JW (2010) Pattern and scale of variability among Northwest Atlantic Shelf plankton communities. J Plankton Res 32:1661-1674

Pettis HM, Rolland RM, Hamilton PK, Brault S, Knowlton AR, Kraus SD (2004) Visual health assessment of North Atlantic right whales (Eubalaena glacialis) using photographs. Can J Zool 82:8-19

Pond CM (1977) The significance of lactation in the evolution of mammals. Evolution 31:177-199

Pond CM, Mattacks CA (1988) The distribution, cellular structure, and metabolism of adipose tissue in the fin whale, Balaenoptera physalus. Can J Zool 66:534-537

Prunier A, Quesnel H (2000) Nutritional influences on the hormonal control of reproduction in female pigs. Livest Prod Sci 63:1-16

Reeb D (2001) Structure, development and composition of the integument of the southern right whale, Eubalaena australis. $\mathrm{PhD}$ dissertation, University of Pretoria, Cape Town

Reeb D, Best PB, Kidson SH (2007) Structure of the integument of southern right whales, Eubalaena australis. Anat Rec 290:596-613

Rice DW, Wolman AA (1971) The life history and ecology of the gray whale (Eschrichtius robustus), Spec Publ 3. American Society of Mammalogists, Stillwater, OK

Right Whale Consorium (2004) North Atlantic Right Whale Consortium Identification Database v. 06/29/2004. New England Aquarium, Boston, MA

> Rosenbaum HC, Brownell RL, Brown MW, Schaeff C, and others (2000) World-wide genetic differentiation of Eubalaena: questioning the number of right whale species. Mol Ecol 9:1793-1802

Simpson JG, Gardiner MB (1972) Comparative microscopic anatomy of selected marine mammals. In: Ridgway $\mathrm{SH}$ (ed) Mammals of the sea-biology and medicine. Charles C. Thomas, Springfield, IL, p 363-378

Thomas VG (1990) Control of reproduction in animal species with high and low body fat reserves. In: Frisch RE (ed) Adipose tissue and reproduction, Vol 14. Karger, Basel, p 27-41

Tormosov DD, Mikhaliev YA, Best PB, Zemsky VA, Sekiguchi K, Brownell RL Jr (1998) Soviet catches of southern right whales Eubalaena australis, 1951-1971. Biological data and conservation implications. Biol Conserv 86:185-197

Tummaruk P, Lundeheim N, Einarsson S, Dalin AM (2001) Effect of birth litter size, birth parity number, growth rate, backfat thickness and age at first mating of gilts on their reproductive performance as sows. Anim Reprod Sci 66: $225-237$

Young RA (1976) Fat, energy and mammalian survival. Am Zool 16:699-710

> Zieba DA, Amstalden M, Williams GL (2005) Regulatory roles of leptin in reproduction and metabolism: a comparative review. Domest Anim Endocrinol 29:166-185 